\title{
Challenges of Immediate Transition to e-Learning
}

\author{
Monja Pust* \\ Fakulteta za organizacijske študije v Novem mestu, Ulica talcev 3, 8000 Novo mesto, \\ Slovenia \\ monja.pust@fos-unm.si
}

Annmarie Gorenc Zoran

Fakulteta za organizacijske študije v Novem mestu, Ulica talcev 3, 8000 Novo mesto, Slovenia

a.zoran@fos-unm.si

\begin{abstract}
:
Research Question (RQ): What challenges did students recognize in the sudden transition to elearning due to the outbreak of COVID-19? Which suggestions facilitated in the improvement of implementing e-learning and to what extent did the students think that following their recommendations contributed to better e-learning?

Purpose: With the research, we wanted to determine what challenges students at higher vocational schools perceived during the e-learning process. Due to the sudden appearance of COVID-19, the educational approach swiftly changed, and both teachers and students were faced with many challenges.

Method: Content analysis was used on domestic and international research studies. The literature was reviewed and analyzed using keywords. For the empirical research, we collected data by surveying students from the southeastern part of Slovenia in seven different short cycle higher education programs. The questionnaire was designed based on self-evaluation reports and previously analyzed professional literature dealing with this area.

Results: Results are depicted based on the challenges that students faced in the sudden onset of elearning due to the pandemic. By following recommendations provided by students, teachers were able to improve their e-learning approach, in which everyone was involved, and thus facilitated the learning process.

Organization: The results of the research enable schools to implement the identified challenges that students perceived during the educational process to improve e-learning. The research findings portray a possible answer on what needs to be improved in e-learning and how to adapt approaches in a way that is tailored to the student.

Society: Recognizing students' e-learning challenges is the foundation for improving the entire elearning process, which contributes to better achievement of educational goals and greater contribution of knowledge to society.

Originality: Several studies on e-learning have already been conducted, but we have not found any that address the challenges posed by short cycle higher education students in the face of the immediate and unexpected introduction of e-learning due to the global health situation.

Limitations/Future Research: We have limited ourselves to research that has already been conducted in this area. The resulting questionnaire was created as a pilot survey on a larger sample to determine reliability and to obtain a starting point for implementing improvements in practice and the possibility of further testing on an even larger number of students. The research also offers a starting point for the preparation of a questionnaire intended for higher education teachers who already have conducted e-learning.
\end{abstract}

Keywords: e-learning, challenges, students, survey questionnaire, online learning, higher education, short cycle programs.

* Korespondenčni avtor / Correspondence author 


\section{Introduction}

Research on e-learning began about three decades ago (Downes, 2005, p. 1), namely because the tools were existent and there was a need in society from non-traditional students, geographical distance, the possibility of including a greater number of students, and opportunity to enrol to lucrative study programs from around the world. In the last decade, however, we have witnessed an increase in e-learning research. The theoretical framework of the phenomenon is also addressed by research which highlights three main dimensions: users, technology, and e-learning services (Aparicio et al., 2016, p. 301).

Educational approaches in this segment have changed and adapted to a fast-growing and developing society. It followed the changes in the global market not only in content but also in how to deliver knowledge. The generation of young people who wanted to use different forms of education also has changed (Downes, 2005, p. 3). Various educational levels started including e-learning, especially in tertiary education. They became accustomed to the changes prudently, gradually and thoughtfully, and most often based on research findings.

In the coming years, students will need new knowledge based on societal needs and also on the basis of the new tools we have, which gives rise to the introduction of new forms of study. All stakeholders in the educational process must be prepared for changes, and the legal basis must be provided. The present research, however, is based on different foundations. Due to the global health crisis caused by the COVID-19, educational institutions, including tertiary education, regardless of how their programs are accredited (i.e., face-to-face, blended learning or distance education), immediately had to find and provide students with an approach that limits physical contact. There was no time to introduce and prepare for a fully integrated e-learning approach. Administrators, teachers and students faced a unique situation. However, students were the ones that need to learn and acquire the objectives, competences, skills that are required of them. The purpose of this research is, therefore, to identify the challenges faced by students. The situation is not improving yet, and e-learning will be integrated into tertiary education in a different way than it has been in the past. As such, a survey was developed and conducted among students to determine advantages, disadvantages, and opportunities. The results would provide insight so that appropriate changes can be made for future academic years. Suma and Kirschner (2020, p. 1) emphasized that with the advent of COVID-19, two important things should not be forgotten when using tools for teaching and that is: (1) the content of what is said and (2) the principles of teaching that effectively convey content.

The research offers answers in terms of challenges students have identified during the sudden transition to e-learning during the outbreak of COVID-19 and which recommendations students provided to improve e-learning. 


\section{Theoretical framework}

E-learning and the concepts related to it are understood very differently in the literature, which is also pointed out by Bregar, Zagmajster, and Radovan (2019, p. 11). The term e-learning in this paper defines both distance learning and blended learning, except where the literature used in the paper explicitly mentions one of the named methods.

Cidral et al. $(2018$, pp. 275,277$)$ treat e-learning as a process in the learning ecosystem. To understand the benefits of e-learning, it is, of course, necessary to determine e-learning user satisfaction. In doing so, the authors developed a model that has been validated among Brazilian students at universities. The findings showed that e-learning changes its foundation between the teacher and student and allows for many new interactions and that the attitude of students and teachers towards e-learning also played a strong role (p. 278).

Studies that identified the advantages or disadvantages of e-learning from different perspectives were all based on the same foundation, namely that students and teachers opted for this type of approach voluntarily. The system was well-established, the advantages and disadvantages were mostly known to all participants, and the participants were informed about the skills needed for such training. However, as far as the authors of this article are informed there have been few studies (Al-Okaily, 2020, p. 1; Azlan et al, 2020, p. 10; Hasan et al., 2020, p. 1; Oyediran et al, 2020, p. 1; Sukendro et al, 2020, p. 1) to explore the benefits and challenges of e-learning / distance learning at a time marked by a sudden transition due to the pandemic (i.e., COVID19). A time when it was not possible to meet face-to-face, it was not voluntary and e-learning / distance learning approaches were largely unknown by administrators, teachers, students, and local communities. Suddenly, teachers had to change their teaching approaches from the traditional brick-and-mortar classroom to an online classroom. There was no time to prepare, the circumstances were new and unknown to everyone, and the results, suggestions and challenges that are highlighted in this study are even more relevant.

Research identifies several challenges in e-learning in a variety of settings. What they all have in common is that they also offer solutions or presented advantages as a counterweight for the discovered challenges. A study that already addressed this issue at the time of the pandemic (Azlan et al., 2020, p. 10) found that when implementing learning and teaching based on elearning platforms, $60 \%$ of students felt that pre-recorded lectures and tutorials and short questions were helpful. Students had to adapt to a new way of learning, teaching. They were challenged by disorders - technical problems, lack of commitment, mental stress. Technical disruptions - poor infrastructure has also led to inefficient inclusion of e-learning in tertiary education (Oyediran et al., 2020, p. 1), and the study recognizes as advantages: broad coverage, cost-effectiveness, uniformity, fast teaching process and learning, rapid economic development through e-commerce. The use of e-learning platforms is also an effective way for the economy to reduce costs, train employees, improve organizational knowledge, update employee skills, and maintain competitiveness in organizations as well (Surber, 2017, p. 156). 
Efficiency as one of the advantages of e-learning has been discussed by many researchers (Chalwell, 2020, p. 115; Khalid, 2020, p. 184; Darrow_Magras, 2015, p. 209-212; Baker, 2018, p. 102; Robbie, 2020, p. 2). The same question is even more at the forefront at a time when this form of learning is the only one offered and possible. Hayashi et al. (2020, p. 139) found that mastering information communication tools (ICT) tools affects users' satisfactions of elearning and continues to be an important variable. Furthermore, it also can influence user's further decision on continuing using ICT tools. The authors further provided an assessment of a relatively important element, which is establishing a synchronous environment; it is about promoting two-way communication where learning and teaching happen at the same time. However, for users to choose to continue their education using e-learning, they are largely not affected by the elements listed above, but by the gap between expectations and experiences. The smaller the gap, the greater the desire to continue with e-learning. (p. 148)

The quality of the system and the quality of the information influence the use of e-learning and user satisfaction (Freeze et al., 2019, p. 173). Freeze et al.'s study revealed that user satisfaction had a stronger impact on the e-learning system compared to using the system. Student satisfaction was higher in the case of providing up-to-date information. Students also highlighted the need for more hardware and software as well as network problems. They also highlighted the time response as a system problem. The study compared different models of determining student satisfaction and found that satisfaction is certainly influenced by students' skills of using ICT tools (p. 179). With the development of ICT, e-learning at the tertiary level has become even more widespread in recent years. Both society and technology are constantly evolving, and consequently, e-learning is adapting to this development and constant changes; the use of new technologies and methodologies seeks to improve the quality, usability, effectiveness, and efficiency of education (Coccoli et al., 2020, p. 329). However, the use of the digital environment in e-learning does not mean improving the learning process, the key emphasis is on how teachers will design the curriculum in e-learning (Gorse et al., 2019, p. 48). In addition to the way the curriculum is designed, it is necessary to be aware that e-learning is sometimes the only possible form of education that increases the share of those involved in tertiary education (Chege, 2019, p. 4), as not all students can study. With greater involvement, it contributes to the expansion of study opportunities to students and, consequently, to modernizing the education system, which has been highlighted during the COVID-19 pandemic (Manu, 2020, p. 138).

Because many users stop learning online, Sun et al. (2008, p. 14) examined factors that influence users' satisfaction of online learning. The study developed an integrated model with six dimensions: students, teachers, lectures, technology, design, and environment. The results of the study found that students' computer anxiety, instructors' attitudes towards e-learning, course flexibility, course quality, perceived usability, ease of use, and diversity of assessment are critical factors influencing student satisfaction, where course quality was assessed as the highest factor. In their study, it showed that the advantages of e-learning are flexibility and 
positive motivation of instructors. They also listed the results with which they advise institutions on how to implement e-learning for greater student satisfaction. (p. 14)

In researching student and teacher satisfaction in the e-learning process of higher education institutions, Al-Samarraie et al. $(2017,1)$ mentioned 11 factors. They emphasized that the key factor of persistence in e-learning is satisfaction, which determines future e-learning in higher education institutions, which they refer to as 'satisfaction in continuing e-learning'. They highlighted five main factors of teachers and students: the quality of information, the adequacy of tasks and technology, the quality of the system, value added and usefulness that significantly influence e-learning satisfaction. (p. 1) The success of students in e-learning largely depends on their satisfaction and content quality, including its implementation, as well as on teacher's ability to connect relevant content with student support, while paying attention to interaction and assessment techniques (Markova et al., 2017, p. 6).

Benefits and satisfaction of e-learning are also influenced by other factors. An analysis of students' e-learning experiences through factor analysis (Loh et al., 2016, p. 11) showed that flexibility and better learning outcomes are the most surprising advantages of e-learning and teaching, with flexibility offering the possibility self-directed learning, a leading factor. Regarding negative perceptions, students pointed out the lack of opportunities for learning together, which also affects the creativity of learning itself, and the inability to access e-learning materials. The authors note that the findings are consistent with research findings from the last decade (e.g., Malhotra, 2002), showing that much has not changed. An additional advantage is also reduced costs. Loh et al.'s study also noted that among the disadvantages, there is no mention of reduced interaction between students and teachers. Disadvantages listed included boredom, loss of motivation, isolation, and self-discipline to maintain motivation (Clark, 2000; Mug, 2001). The differences in younger and older students were also presented, younger students emphasized the importance of socializing, meeting new people, face-to-face interactions with teachers. Disadvantages with older students are not seen to such an extent. (Loh et al., 2016)

Research in the study and comparison of e-learning, blended learning and direct learning in lecture halls found that learning and teaching are extremely complex processes, depending on several variables and not only on results, satisfaction, and forms of education (Nortvig et al., 2018, p. 46). Nortvig et al.'s (2018) results showed that there are certain factors that are more visible than others, such as the presence of the teacher and the interaction between students and teachers. In blended learning, the design should be to promote coherence between online and face-to-face learning as well as between students, teachers, and the content itself. (p. 46)

The success of students in e-learning largely depends on their satisfaction and the way the teachers design and implements lessons, as well as on the teacher's ability to link relevant content to student support and pay attention to interaction and assessment techniques (Markova et al. (2017, p. 6). Almarashdeh and Alsmadi (2016, p. 4) also pointed out a key element that 
plays an important role for students, namely the applicability and simplicity of ICT technology in e-learning.

Palgrave et al. (2016, p. 17) also identified design, timely and individualized feedback, which is crucial in an online learning environment. They recommended that higher education develop personalized, flexible learning to avoid challenges. One study, however, offers a different view, namely that students perceive the use of ICT technology as the most successful in group work (Lamb et al., 2020, p. 298).

The advantages of e-learning can be considered from three angles, namely from the perspective of education participants (i.e., flexibility of time, place, pace; faster access to knowledge; adaptation of learning approaches; transparency of conditions; development of new knowledge), from the perspective of educational organizations (i.e., reduction of costs; better services; transparency of programs; objectification of assessment; access to learning resources; modern pedagogical models; better opportunities for marketing programs); and from the point of view of organizations as users of educational services (i.e., traditional; cheaper organization, faster implementation; use of available technology; improving information literacy; adapting content to the needs of the company). (Bregar et al., 2020, pp. 21-22)

Countries that are implementing the use of ICT tools face many challenges and use the experience of leading countries in the field of e-learning for students and teachers (Shahmoradi et al., 2018, p. 1). Other challenges of e-learning are also the initial input, technophobia, personal interaction, control and socialization (Potočnik, 2016, p. 24).

Critical elements in today's society are many and two of them are lack of time and costs of education, which could be eliminated by introducing structure of academic mobility programs. Academic mobility programs pursue a goal such as the development of the information society through a gradual transition to a knowledge society, with the global education market posing the problem of creating a new model of e-learning (Davidovitch \& Belichenko, 2016, pp. 178179). Mobility programs would mitigate both negative aspects through e-learning. Thus, the introduction of e-learning is one of the possible solutions to eliminate or mitigate these problems, which often occur in modern society. Otherwise, in addition to cost savings, uninterrupted accessibility and convenience are recognized as advantages (Uppal, 2017, pp. 46), which facilitates education for anyone anytime, anywhere.

As one of the offered solutions in e-learning is multimodality (Ferri et al., 2018, p. 86), which enables the creation of several knowledge presentations; thus, learning contents are given in different ways, e.g., using video, audio, text. The use of e-materials in the context of e-learning, which is continuously accessible, also presents challenges (Cigler, 2016, pp. 8, 54) in connection with plagiarism, lack of teacher authority (p. 8), technical difficulties, and difficulty in providing attention (p. 54). The razlagamo.si movement, discussed in the article by Pesek, Zmazek, and Lipovec (2020, p. 1) offers asynchronous explanations of pre-prepared and 
recorded materials, which can be used by everyone who is studying at the time of COVID-19. They suggest further interactions with the material prepared in advance. By doing so, they try to reduce the challenges that the participants of the educational process faced.

Following is a summary of possible answers or contributions of e-learning provided in the literature review above (see Table 1). Table 2 summarizes the challenges identified in the various studies outlined related to e-learning.

Table 1. Possible answers or contributions of e-learning

\begin{tabular}{|c|c|}
\hline Possible answers / contribution of e-learning & Research findings \\
\hline $\begin{array}{l}\text { Satisfaction with the relationship between students } \\
\text { and teachers }\end{array}$ & Sticker et al. (2011) \\
\hline $\begin{array}{l}\text { Pre-recorded lectures, tutorials, short questions are } \\
\text { helpful }\end{array}$ & Azlan et al. (2020); Pesek et al. (2020) \\
\hline Wide coverage & Overdiran et al. (2020); Uppal (2017) \\
\hline Cost efficiency & $\begin{array}{l}\text { Overdiran et al. (2020); Bregar et al. (2020); } \\
\text { Davidovitch et al. (2016); Uppal (2017) }\end{array}$ \\
\hline Unity & Overdiran et al. (2020) \\
\hline Fast process of teaching, learning, feedback & $\begin{array}{l}\text { Overdiran et al. (2020); Freeze et al. (2019); Bregar } \\
\text { et al. (2020); Davidovitch et al. (2016) }\end{array}$ \\
\hline $\begin{array}{l}\text { Rapid economic development through e-commerce; } \\
\text { use of e-learning platforms }\end{array}$ & $\begin{array}{l}\text { Overdiran et al. (2020); Surber (2017); Bregar et al. } \\
(2020)\end{array}$ \\
\hline Greater efficiency & $\begin{array}{l}\text { Chalwell (2020); Khalid (2020); Darrow_Magras } \\
\text { (2015); Baker (2018); Robbie (2020) }\end{array}$ \\
\hline ICT management and use & Hayashi et al. (2010); Bregar et al. (2020) \\
\hline $\begin{array}{l}\text { Improving the quality, usability, efficiency of } \\
\text { education }\end{array}$ & $\begin{array}{l}\text { Coccoli et al. (2020); Manu (2020); Bregar et al. } \\
(2020)\end{array}$ \\
\hline Flexibility & $\begin{array}{l}\text { Sun et al. (2008); Loh et al. (2016); Bregar et al. } \\
(2020)\end{array}$ \\
\hline Quality, useful information & Al-Samarraie et al. (2017); Bregar et al. (2020) \\
\hline Development of personalized learning & Palgrave et al. (2016) \\
\hline ICT enables more successful teamwork & Lamb et al. (2020) \\
\hline Objectification of assessment & Bregar et al. (2020) \\
\hline Comfort & Uppal (2017) \\
\hline Multimodality (use of video, sound) & Ferri et al. (2018) \\
\hline
\end{tabular}

Table 2. E-learning challenges

\begin{tabular}{l|l}
\hline E-learning challenges & Research findings \\
\hline Technical problems & $\begin{array}{l}\text { Azlan et al. (2020); Overdiran et al. (2020); Freeze et } \\
\text { al. (2019); Loh et al. (2016); Cigler (2016) }\end{array}$ \\
\hline Lack of commitment & Azlan et al. (2020); Loh et al. (2016); Cigler (2016) \\
\hline Stress & Azlan et al. (2020); Sun et al. (2008) \\
\hline ICT skills & Freeze et al. (2019); Sun et al. (2008) \\
\hline The attitude of instructors towards e-learning & Sun et al. (2008) \\
\hline Diversity of assessment & Sun et al. (2008) \\
\hline Lack of shared learning & Loh et al. (2016) \\
\hline Untimely feedback & Palgrave et al. (2016) \\
\hline Initial investment & Potočnik (2016) \\
\hline Personal interaction & Potočnik (2016) \\
\hline Use of e-materials (plagiarism, accessibility) & Cigler (2016) \\
\hline Lack of teacher authority & Cigler (2016) \\
\hline
\end{tabular}


Based on the review of literature, the following hypotheses were developed:

Hypothesis 1: Students provide more suggestions based on frequency for improvements than positive remarks during COVID-19 e-learning.

Hypothesis 2: Students are more satisfied with e-learning during COVID-19 than with traditional face-to-face classes.

Hypothesis 3: Students turn to teachers or classmates for assistance in working with the online classroom than they can do independently.

Using a questionnaire with closed- and open-ended types of questions, we wanted to examine the research question on the challenges students recognized in the immediate transition to elearning due to the COVID-19 outbreak. In addition, we examined the suggestions they provided to improve the implementation of e-learning and to what extent, in the opinion of the students, did their adherence to their suggestions contribute to better e-learning. For the first part of the research question, we conducted it during the beginning of e-learning as a result of COVID-19 and for the second research questions, the survey was conducted again at the end of the Spring semester, which considered the suggestions of students from the first survey. For the survey, we purposefully decided that students should provide their feedback on e-learning specifically, which encouraged them to think critically, leading to self-efficacy, which is crucial for e-learning to succeed (De Silva, 2019, p.7).

\section{Method}

We reviewed the literature in e-learning limiting ourselves mainly to research after 2015, which touched on the topic or offered data that we could use to develop a questionnaire. Primary data were obtained with the survey, secondary with the review of the literature. We relied on databases SpringerLink, ScienceDirect, Scopus, Web of Science, dLib, and COBISS. The following English keywords were used for the search: e-learning, distance learning, challenges of e-learning, evolution of e-learning, the role of e-learning, blended e-learning, student satisfaction of e-learning, traditional vs distance learning, traditional vs e-learning, traditional vs blended learning. We also used the Slovenian equivalent keywords.

The questionnaire was compiled using existing literature and self-evaluation reports of higher education vocational schools (short cycle) in southeastern Slovenia. The questionnaire was prepared by a quality committee by one of the higher vocational schools. The questionnaire was piloted using 28 completed surveys. The questionnaire was also tested for internal consistency using the Cronbach Alpha test. The reliability shown by the test is very good, as the value of the Cronbach Alpha test is $0.83(95 \% \mathrm{CI}$; confidence interval $=0.73 ; 0.94)$. It was distributed among full-time students of seven different study programs in a higher education vocational school (short cycle) in southeastern Slovenia. The survey was conducted at the beginning of the lockdown (March 2020), when the higher education system was fully subject to implementing distance learning. The survey was in Slovenian and contained nine areas (i.e., study program, comprehensibility of instructions in the online classroom, timely publication of instructions, 
suggestions for improvement, assistance, implementation through the same communication channel, implementation according to the schedule, satisfaction with lectures on a single channel, given proposals). It was designed in such a way that the participants were offered potential responses to the challenges of e-learning, and in six instances, respondents had the opportunity to supplement the answer. Challenges were analyzed and considered in the further implementation of e-learning, after completing the first survey. Recommendations were given to teachers and the implementation of the pedagogical process was organized in such a way that the suggestions of students were considered. At the end of the semester, students completed the same survey. Once again, respondents were able to provide challenges that they faced. Based on their responses and a comparison of the two survey results, we analyzed challenges that could be solved in relatively short period of time and which ones that need to be tackled face on in case of further e-learning or complete distance learning in the near future. The obtained data were processed using Microsoft Excel and Microsoft Word, statistical software package $\mathrm{R}$, and parametric tests was used. With the help of the latter, we tested the hypotheses. The first survey was completed by $64 \%$ Year 1 and Year 2 students, and the second survey by $72 \%$ of students - only Year 1 students participated in it, namely because Year 2 students had practical education.

The research was conducted in 4 steps: (1) data collection, (2) development of a theoretical model and measuring instruments, (3) data analysis, (4) reliability and validity of constructs and data, as shown in Figure 1.

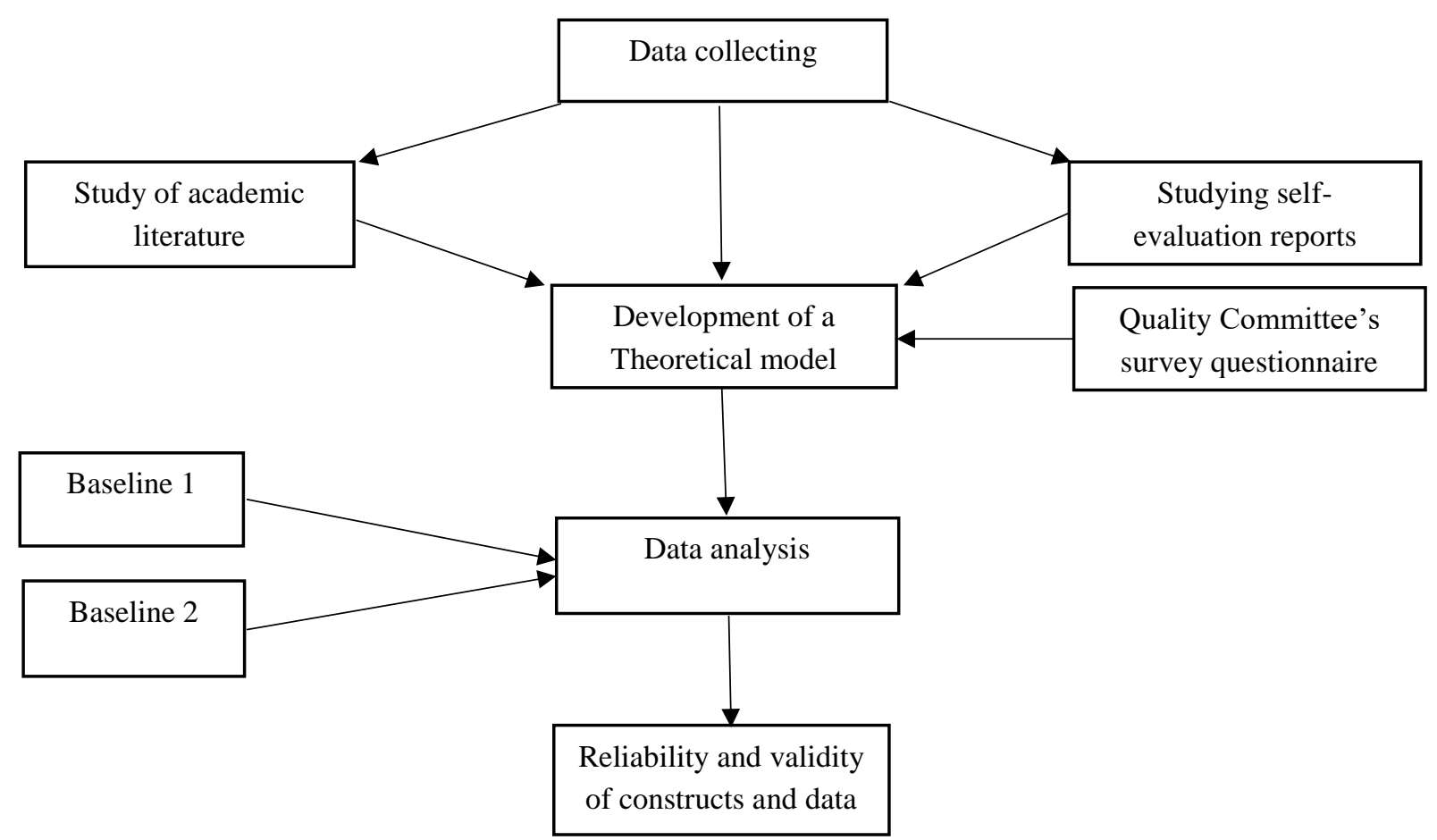

Figure 1. Research model 


\section{Results}

The anonymous survey completed by full-time higher education vocational short cycle students in higher education in southeastern (SE) Slovenia was conducted twice, the first time between the 2 and 4 April 2020 and was repeated between 29 May and 4 June 2020. The first survey included Year 1 and Year 2 students, the sample was distributed among 398 students, 292 of them attempted the survey, and 261 students completed the survey, which represented $65.58 \%$ of the students who were surveyed. Fewer students were included in the second survey, namely Year 1 students were included, because after the first survey, Year 2 students completed practical training and no longer received the same teaching method as during the first survey. The second survey was distributed to 230 students, 192 students attempted to complete it, and 165 completed the survey, which represents $72 \%$ of the students to whom the survey was forwarded. The data are tabulated in Table 3.

Table3. Student type and size

\begin{tabular}{lcc}
\hline & 1st Survey & 2nd Survey \\
\hline Survey time & $2-4$ April 2020 & 29 May - 4 June 2020 \\
\hline Surveyed full-time students & Year 1 and Year 2 & Year 1 \\
\hline Student population & 398 & 230 \\
\hline $\begin{array}{l}\text { No. of students who attempted } \\
\text { completing the survey }\end{array}$ & 292 & $\mathbf{1 6 5}(\mathbf{7 2} \%)$ \\
\hline $\begin{array}{l}\text { No. of students who completed } \\
\text { the survey completely }\end{array}$ & $\mathbf{2 6 1 ( 6 5 , 5 8 ~ \% )}$ & \\
\hline
\end{tabular}

Note. We further analysed, whether the proportion of students who completed the survey in full increased statistically significantly in the 2nd survey at the $p>.05$, which means that it was not statistically significant.

The statistical value of the tested hypothesis (whether the proportion of students who completed the survey increased statistically significantly in the 2nd survey compared to the 1st survey) shows that there is no statistically significant increase in completed surveys, which were performed for the second time.

The survey was completed by students who were enrolled in seven different programs, as shown in Table 4. We compared the program distributions between the samples (Survey 1 and Survey 2). We tested by comparing the proportions using a chi square test. We can say with certainty that the distributions are similar. The claim is also confirmed by a comparison of the proportions by programs between the first and second survey. 
Table 4. Number of students in various programs who completed the survey in full

\begin{tabular}{lcc}
\hline Programs & 1st Survey & 2nd Survey \\
\hline Program 1 & 22 & 17 \\
\hline Program 2 & 34 & 23 \\
\hline Program 3 & 75 & 42 \\
\hline Program 4 & 24 & 13 \\
\hline Program 5 & 9 & 16 \\
\hline Program 6 & 74 & 42 \\
\hline Program 7 & 23 & 12
\end{tabular}

Note. A value of chi square of the test indicates that $p>.05$; which means that we cannot reject the hypothesis (the distributions are different).

The comprehensibility of the instructions given in the online classrooms was calculated slightly more for survey one $\left(\mathrm{X}^{-}=4.01\right)$ with .02 points less for survey two $\left(\mathrm{X}^{-}=3.99\right.$; see Table 5$)$. A t-test was used to determine whether the average in the second survey was statistically significantly greater than three (the mean) and whether there was a statistically significant improvement in the average between the first and second surveys. We tested whether the difference between the averages was statistically significantly equal to 0 . It means that we cannot claim that there is a difference in the sample between the means of the first and the second survey. A visual analog scale was used to test other Likert scales.

Table 5. Understanding online classroom instructions while working remotely

\begin{tabular}{lcc}
\hline & 1st Survey & 2nd Survey \\
\hline Completely understandable (5) & 86 & 58 \\
\hline Quite understandable (4) & 113 & 55 \\
\hline They are partially understandable (3) & 42 & 38 \\
\hline They are mostly incomprehensible (2) & 15 & 9 \\
\hline They are incomprehensible (1) & 5 & 1 \\
\hline Mean rating & $\mathbf{3 . 0 9 9}$ & $\mathbf{3 . 8 9}$
\end{tabular}

Note. The first statement that the average is less than or equal to 3 means that $p=0 ; \alpha=.05$; the average in the second survey is statistically significantly higher than 3 . The second statement that the average in the second survey is higher than the average in the first survey means that $p>.05, \alpha=.05$, the hypothesis is not rejected.

Timely publication of instructions was calculated slightly more for survey two $\left(\mathrm{X}^{-}=4.07\right)$, with 0.02 points less for survey $1\left(\mathrm{X}^{-}=4.05\right.$; see Table 6$)$. Statistical comparison of means between surveys regarding the timeliness of publication of instructions does not bring us any statistical deviation. 
Table 6. Timely publication of instructions in the online classroom

\begin{tabular}{lcc}
\hline & 1st Survey & 2nd Survey \\
\hline Completely understandable (5) & 90 & 56 \\
\hline Quite understandable (4) & 114 & 70 \\
\hline They are partially understandable (3) & 37 & 35 \\
\hline They are mostly incomprehensible (2) & 15 & 3 \\
\hline They are incomprehensible (1) & 5 & 1 \\
\hline Average rating & $\mathbf{4 . 0 3}$ & $\mathbf{4 . 0 7}$
\end{tabular}

Note. Assuming that the average is greater than $3, p=0$, which means that we reject the hypothesis, consequently there is a statistically significant difference and therefore we can say with some certainty that the average is greater than 3. The argument of comparing averages between surveys illustrates that $p>.05$.

Table 7 presents student suggestions for online classrooms. Most of the comments were that everything was fine. According to the first survey, a total of $5.9 \%$ of all students provided such an answer, the number increased to $10.9 \%$ after the second survey, which is encouraging and suggests that certain suggestions were considered. One suggestion made was for instructions to be clearer, in the first survey $3.6 \%$ of students provided this suggestion, and after the second survey $4.8 \%$. The suggestion made after the first survey that instructions should be given earlier, which represents $3.6 \%$ of students' comments, was reduced to $1.2 \%$ after the second survey. The result suggested certain suggestions were considered by the first survey. The need for notification by e-mail, which was expressed after the first survey at $2 \%$, decreased to $0.6 \%$ after the second survey. Other suggestions were the timely submission of deadlines for exams and midterms, which according to both surveys represents $1.2 \%$ of all students. After the second survey, there were suggestions for better ICT servers $(2.4 \%)$, clearer instructions $(1.2 \%)$ and submission of assignments in one place (0.6\%). Other suggestions after the first survey, which appeared once, are no longer detectable in the second survey. The proportion of students who did not provide comments increased statistically significantly between the two surveys. 
Table 7. Suggestions for improving online classes

\begin{tabular}{lcc}
\hline Suggestions & 1st Survey & 2nd Survey \\
\hline Everything is fine. Answers without a suggestion. & $15(5.9 \%)$ & $18(10.9 \%)$ \\
\hline Task instructions could be written more clearly, consistently. & $9(3.6 \%)$ & $8(4.8 \%)$ \\
\hline Instructions for the tasks should be published at least a day in advance. & $9(3.6 \%)$ & $2(1.2 \%)$ \\
\hline More e-mail notifications. & $5(2.0 \%)$ & $1(0.6 \%)$ \\
\hline Timely submission of deadlines and instructions for colloquia of exams. & $3(1.2 \%)$ & $2(1.2 \%)$ \\
\hline A better server, that do not crash, especially during the exam. & $/$ & $4(2.4 \%)$ \\
\hline Not to get too many tasks at once. & $3(1.2 \%)$ & $/$ \\
\hline The complexity of the tasks should be less. & $2(0.8 \%)$ & $/$ \\
\hline $\begin{array}{l}\text { In the case of individual subjects, the instructions are completely } \\
\text { incomprehensible. }\end{array}$ & $/$ & $2(1.2 \%)$ \\
\hline Assignments should be submitted in one place only. & $1(0.4 \%)$ & $1(0.6 \%)$ \\
\hline Some teachers do not know how to best manage an online classroom. & $1(0.4 \%)$ & $/$ \\
\hline There were no preparations for video conferencing. The lectures are & $1(0.4 \%)$ & $/$ \\
\hline under pressure of deadlines. & $1(0.4 \%)$ & $/$ \\
\hline Clearly write down content intended for full-time and part-time students. & $1(0.4 \%)$ & $/$ \\
\hline Post when changing a subject in the online classroom. & $1(0.4 \%)$ & $/$ \\
\hline Automatic reminder to submit tasks before the deadline. & $1(0.4 \%)$ & $/$ \\
\hline $\begin{array}{l}\text { The obligation to be present at the videoconference call should be } \\
\text { skipped and only assignments submitted. }\end{array}$ & $1(0.4 \%)$ & $/$ \\
\hline Class could be from 11 a.m. onwards and not earlier. & $21.5 \%$ & $22.9 \%$ \\
\hline Together & 1 & / \\
\hline
\end{tabular}

Note. The value of $p<.05$ in determining the proportion of students who were without comments between the two surveys and increased statistically significantly.

Most often, assistance to students was provided by teachers, which is seen in Table 8, namely $66 \%(f=172)$ students according to the first survey and $58 \%(f=96)$ students according to the second survey. In the first survey, $69 \%(f=181)$ students turned to their classmates for assistance, and $72 \%(f=118)$ after the second survey. The fact that they can do it on their own without help also increased from $26 \%$ in the first survey to $30 \%$. However, the proportion of students who expressed that no one assisted them but would need assistance in the first or second survey increased by $2 \%$. Statistical data analysis shows that we cannot claim that the proportion of students who did not need assistance has increased statistically significantly.

Table 8. Staff who offered assistance with the online classroom

\begin{tabular}{lcc}
\hline Online classroom help & 1st Survey & 2nd Survey \\
\hline Teachers & $172(66 \%)$ & $96(58 \%)$ \\
\hline Classmates/other students. & $181(69 \%)$ & $118(72 \%)$ \\
\hline No one, but I would need help. & $8(3 \%)$ & $9(5 \%)$ \\
\hline I can do it alone; I do not need help. & $66(25 \%)$ & $50(30 \%)$ \\
\hline
\end{tabular}

Note: With the value of $\mathrm{p}<.05$ in the hypothesis (the share of students who do not need help working with the online classroom increased), we cannot claim that the proportion of these students increased statistically significantly. 
Table 9 shows the numerical value of consistent use of unified videoconferencing call in conducting classes. Unified videoconferencing call refers to all members using one platform (i.e. MS Teams, Zoom, WebEx) instead of using different platforms. In the first survey, the this was confirmed by $75 \%$ students $(f=196)$, in the second survey the percentage increased, namely to $93 \%(f=154)$ students. We found that the number of affirmative responses increased statistically.

Table 9. Conducting class via unified video conference call

\begin{tabular}{lcc}
\hline Answer & 1st Survey & 2nd Survey \\
\hline Yes & $196(75 \%)$ & $154(93 \%)$ \\
\hline No & $65(25 \%)$ & $11(7 \%)$ \\
\hline
\end{tabular}

Note: A value of $p<.05$ and is above the level of characteristics.

As shown in Table 10, the implementation of classes after the videoconference call, in line with the course schedule, also increased, with $88 \%(f=230)$ students after the first survey and $98 \%(f=161)$ students after the second survey agreeing with this response. We found that the number of affirmative answers increased statistically.

Table 10. Conducting class via unified videoconferencing based on the course schedule

\begin{tabular}{lcc}
\hline Answer & 1st Survey & 2nd Survey \\
\hline Yes & $230(88 \%)$ & $161(98 \%)$ \\
\hline No & $31(12 \%)$ & $4(2 \%)$ \\
\hline
\end{tabular}

Note: A value of $p<.05$ and is above the level of characteristics.

The average value of satisfaction with classes conducted via a unified videoconferencing call after both surveys was on average at 4.05 (see Table 11). The statistical comparison was not statistically significant.

Table 11. Satisfaction with class using the unified video conference call

\begin{tabular}{lcc}
\hline Completely understandable (5) & 1st Survey & 2nd Survey \\
\hline Quite understandable (4) & 95 & 66 \\
\hline They are partially understandable (3) & 109 & 57 \\
\hline They are mostly incomprehensible (2) & 42 & 30 \\
\hline They are incomprehensible (1) & 7 & 8 \\
\hline Average rating & 8 & 4 \\
\hline
\end{tabular}

Some students responded with a comment. Compliments was given by $26 \%(f=68)$ students at the end of the first survey and $15 \%(f=24)$ students at the end of the second survey. $17 \%$ $(f=44)$ students submitted comments after the end of the first survey and $12 \%(f=20)$ students at the end of the second survey. There were also more suggestions in the first survey, namely $11 \%$ of students, in the second survey $4 \%$ of students, which is listed in Table 12. It is 
statistically significant that the share of praise is higher than the share of suggestions; we rejected the first hypothesis that there are more suggestions than compliments.

Table 12. Suggestions, compliments, comments

\begin{tabular}{lcc}
\hline & 1st Survey & 2nd Survey \\
\hline Compliments & $68(26 \%)$ & $24(15 \%)$ \\
\hline Comments given & $44(17 \%)$ & $20(12 \%)$ \\
\hline Suggestions & $29(11 \%)$ & $7(4 \%)$
\end{tabular}

Note: A value of $p<.05$ and is above the level of characteristics.

Compliments according to the first survey referred to all teachers and school administrators (7.9 \%), compliments to individual teachers (3.2\%), and the last two compliments were indented for management for quick organization and technical assistance (respectively $2 \%$ each), which can be seen in Table 13.

Table 13. Compliments after the first survey

\begin{tabular}{lcc}
\hline & Freq. & $\mathbf{\%}$ \\
\hline Compliments to all the teachers and school administration & 20 & $7.9 \%$ \\
\hline Compliments to individual teachers. & 8 & $3.2 \%$ \\
\hline Compliments to the management for quick organization. & 5 & $2.0 \%$ \\
\hline Compliment for technical help. & 5 & $2.0 \%$ \\
\hline
\end{tabular}

The comments shown in Table 14 after the first survey referred to the abundance of work by $4 \%$ of students, problems with technology were exposed by $1.6 \%$, non-response of teachers and unclear instructions on the use of videoconferencing were statements that occurred in $1.2 \%$, the rest in less than $1 \%$.

Table 14. Comments made after the first survey

\begin{tabular}{lll}
\hline & Frequency & $\%$ \\
\hline There is too much work, more tasks than usual ... & 10 & $4.0 \%$ \\
\hline Occasional sound interruption, connection problems, system load. & 4 & $1.6 \%$ \\
\hline Unresponsiveness of individual lectures. & 3 & $1.2 \%$ \\
\hline $\begin{array}{l}\text { There were no clear instructions for a video conference call, the first } \\
\text { approach was difficult. }\end{array}$ & 3 & $1.2 \%$ \\
\hline $\begin{array}{l}\text { The video conferencing environment is challenging and pointlessly } \\
\text { designed. }\end{array}$ & 1 & $0.8 \%$ \\
\hline Not quite clear obligations we have. & 1 & $0.4 \%$ \\
\hline Noise and too many people in the call. & 1 & $0.4 \%$ \\
\hline That you must have the camera on. & $0.4 \%$ \\
\hline
\end{tabular}

Table 15 presents suggestions for better instructions for conducting classes, exercises, exams by $2 \%$ of students, with $1.6 \%$ representing suggestions for fewer assignments and more free time. Other suggestions provided were by less than $1 \%$ of students. 
Table 15. Suggestions provided after the first survey

\begin{tabular}{lll}
\hline & Frequency & $\%$ \\
\hline $\begin{array}{l}\text { Better instructions for conducting lectures, exercises, conducting } \\
\text { exams ... }\end{array}$ & 5 & $2.0 \%$ \\
\hline Fewer tasks, more free time & 4 & $1.6 \%$ \\
\hline Part of the class could be given even after the epidemic & 2 & $0.8 \%$ \\
\hline Recording lectures & 2 & $0.8 \%$ \\
\hline Phased approach when introducing a videoconferencing call & 1 & $0.4 \%$ \\
\hline Additional help fort overworked lectures & 1 & $0.4 \%$ \\
\hline Most grades are obtained through seminar papers & 1 & $0.4 \%$ \\
\hline
\end{tabular}

Table 16 provides comments after the second survey, of which there were very few. All comments were given as suggestions for improvements and each of the four appeared once, which is below $1 \%$ of all respondents.

Table 16. Suggestions provided after the second survey

\begin{tabular}{lll}
\hline & Frequency & $\%$ \\
\hline That the instructions, given to students, also follow the classes. & 1 & $0.7 \%$ \\
\hline To reward the online classroom and make it more transparent. & 1 & $0.7 \%$ \\
\hline If possible, link notifications to emails to make new post clearer. & 1 & $0.7 \%$ \\
\hline $\begin{array}{l}\text { To enable distance learning in addition to full-time and part-time } \\
\text { studies in the next academic year. }\end{array}$ & 1 & $0.7 \%$ \\
\hline
\end{tabular}

\section{Discussion}

At the beginning of the COVID-19 epidemic, the student satisfaction survey at vocational colleges (higher education short cycle programs) in SE Slovenia covered seven study programs with 261 students, which represents $65.58 \%$ of all Year 1 and Year 2 students. The survey was repeated for the second time at the end of the Spring semester and included 165 Year 1 students (NB. Year 2 students were under practical training), representing $72 \%$ of respondents. The comparisons showed that we cannot claim that in the second survey students completed the survey in large numbers, although the $p$-value is extremely close to the level of characteristics. We compared the program distributions between the samples (Survey 1 and Survey 2) with a chi-square test. We did not confirm the hypothesis (the distributions are different), but we can say with some certainty that the distributions are similar, which is also confirmed by the comparison of proportions by programs between the two surveys.

The students were satisfied with the comprehensibility of the instructions given in the online classrooms, with a mean score of approximately 4 after both surveys. The mean score dropped slightly, which could have been due to additional assignments and workloads with upcoming exam deadlines, so there were also slightly more instructions than at the very beginning of 
distance learning. With the $t$-test we found that we cannot claim that there is a difference in the sample between the first and second surveys.

The timely publication of the instructions was also highly rated by the students (Survey $1=$ 4.05; Survey $2=4.07$ ). Comparing the means between surveys was not statistically significant.

All students entered distance learning because of the pandemic and not based on their own choice, so in the survey we wanted to determine their suggestions related to distance learning. Students also made suggestions for improving distance learning (i.e., study, field work, homework). Between the first and second survey, the percentage of students who determined that everything was fine increased by $4.8 \%$, which indicates that the students' suggestions for improving this type of mode were considered by teachers and administration. The number of suggestions under clearer instructions increased by $1.2 \%$. After the end of the second survey, there were more assignments, the exam deadlines were approaching and there were more instructions, so there was a noticeable increase. However, the number of suggestions on the timeliness of instructions decreased by $1.2 \%$, which again indicates that their proposals were considered according to the first survey. The need for notification by e-mail, which was expressed in $2 \%$ after the first survey, decreased to $0.6 \%$ after the second survey. The result could indicate that students have mastered working with an online classroom and accessing the information. Other suggestions were the timely submission of deadlines for exams and midterms, which according to both surveys represents $1.2 \%$ of all students. After the second survey, there were suggestions for better ICT servers $(2.4 \%)$, clearer instructions $(1.2 \%)$ and submission of tasks in one place $(0.6 \%)$. Other suggestions made after the first survey were no longer detectable in the second survey. The share of students without comments also increased statistically significantly between the two surveys.

Comprehensibility and timely publication of instructions affect student satisfaction, as they show greater efficiency of the learning process (the result represents a value of 4 or more after both surveys in terms of comprehensibility and timeliness). The need to use e-mail has also decreased due to students experience with the online classroom.

However, the exposed challenges that have arisen in this situation can be identified with previously identified research. As stated by Hayashi et al. (2020, p. 139), mastering ICT technology has an impact on greater satisfaction in education itself and consequently on the effectiveness of the learning process. Some insisted on this form of education rather than on the direct impartation of knowledge. Students who completed the surveys also had to adopt a new type of teaching and learning. The extent to which this had affected the effectiveness of the study itself should be further examined. However, there was a proposal to continue e-learning where students made suggestions for improving the learning process.

The results by Freeze et al. (2019, p. 173), are also applicable in this study, as the suggestions provided were on similar segments: providing up-to-date information (Chawinga, Zozie, 2016, 
p. 16), more hardware and software, network problems, time response as a system problem. A correlation can also be sought with the following findings of Sun et al. (2008, p. 14) that anxiety among students is represented by the lack of an e-learning course, ease of use, and diversity of assessment, which are critical factors. The students suggestions that were also recognized as some of the challenges by Al-Samarraie et al. $(2017,1)$ : quality of information, suitability of tasks and technology, quality of system. The usability and simplicity of the ICT program can also be traced in our research as well as in Almarashdeh and Alsmada (2016, p. 4).

Teachers were most often assisted by fellow teachers (a decrease of $8 \%$ was detected between Survey 1 and Survey 2), followed by classmates (an increase of 3\% was detected between Survey 1 and Survey 2). Due to the more skilful use of ICT, assistance among students had become more prominent. The number of students who did not need help after the Survey 2 also increased by $4 \%$, while the number of those who would need help but did not receive it increased by $2 \%$. The latest data most likely shows a decline in the motivation of individual students in this type of education and a lack of interest in seeking help. Statistically, we cannot claim that the proportion of students who do not need help has increased statistically significantly.

In addition to mastering ICT technology, Hayashi et al. (2020, p. 139), when they add importance to the establishment of a synchronous environment, the promotion of two-way communication (p. 148). Synchronous communication is also provided by video conferencing. Students did not use it before the pandemic, so they wanted to establish a single videoconferencing call using the same app for all students and lecturers.

Consistent use of the unified videoconferencing calls in conducting classes increased by $18 \%$ during both surveys, which indicates a more consistent use of the single videoconferencing call due to better handling of ICT technology by teachers. Video conference call was conducted at the time as scheduled in the schedule and the value of taking this into account has also increased by $10 \%$. The results indicate that the comments made after the first survey have been considered by administrators and teachers. We found that in both cases, the number of affirmative responses increased statistically. The use of videoconferencing clicks during the presence of Covid 19, which put the entire education system ahead of the use of various e-learning tools, is evolving and changing, otherwise considering suggestions in bottom-up experiences such as Correia, AP, Liu, C. and Xu, F. (2020, p. 20).

Satisfaction with a different approach to teaching did not change after the Survey 2, the average value remains the same, namely 4.05 . Even the statistical comparison does not bring us any significant deviation.

Fewer students responded to the comments in the Survey 2 than in the Survey 1, 11\% fewer compliments, $5 \%$ fewer comments and $7 \%$ fewer suggestions for improvement. The number of comments and suggestions fell in the Survey 2, namely because students had become familiar 
with online learning for several weeks and the reason for the decrease in praise due to less assistance from teachers as indicated.

Fewer comments were expected after the second survey. The reason can be seen from the data in Table 7, where the percentage of students who thought that everything was fine with distance learning doubled. Students' suggestions and challenges were largely considered, as is evident from the second survey, in which certain suggestions or challenges no longer appeared or were represented to a lesser extent. Satisfaction with e-learning had been maintained. It can be concluded that the students' suggestions were considered, but that satisfaction itself was not affected in a way that would be evident from the research. The students were informed on the results of the survey and thus received feedback on suggestions and improvements in the implementation of distance learning. Statistically, the share of compliments is higher than the share of suggestions; we rejected the first hypotheses that there are more suggestions than compliments. The first hypothesis that students made more suggestions than compliments in the implementation of e-learning is rejected, as it is obvious and statistically significant that the share of compliments was significantly higher than the share of suggestions between the two surveys. We also tested whether the share of suggestions decreased statistically significantly between the first and second surveys and they did not.

The second hypothesis, which stated that students were satisfied with e-learning, can be confirmed by the data in Table 5, Table 6 and Table 11. The average score on the comprehensibility of instructions in the online classroom was 4.0 on the Likert scale. The analysis of answers given for timely publications of instruction, satisfaction with classes, and classes via videoconferencing calls determined satisfaction with e-learning, which based on values equal to 4.0 or higher is assessed positively; although this showed that we cannot claim whether there was indeed a statistically significant improvement with satisfaction between the first and second survey. The distribution of responses changed slightly, although not statistically significantly.

The third hypothesis that a larger proportion of students turn to teachers or classmates for assistance in working with the online classroom than they can do on their own cannot be confirmed or rejected, as we cannot statistically determine whether the proportion of students who do not need help statistically significantly increased.

By analysing the survey, we confirmed two hypotheses out of three, the last hypothesis is neither confirmed nor rejected. The situation the students found themselves in had never been like this before. Previous research on the advantages and disadvantages of e-learning addresses them in those students who have voluntarily opted for e-learning and have already been introduced to this type of teaching. This year, however, all students were suddenly transformed to e-learning. Aware of this fact, students did not look for weaknesses and strengths between face-to-face teaching and e-learning, but cited suggestions, weaknesses, and compliments based 
on the existing and current situation. Due to the latter, it is not possible to make a direct comparison of certain findings with previous research in this field.

\section{Conclusion}

The purpose of our research was to determine the challenges students identified in the immediate transition to e-learning due to the COVID-19 pandemic, suggestions and items that need to be improved, and to what extent, in the opinion of the students, did their adherence to their suggestions contribute to better e-learning.

Two of the three hypotheses have been confirmed, namely that students make more suggestions for improvements than compliments and that they are satisfied with the way distance learning was conducted. The third hypothesis, that a larger proportion of students turn to teachers or classmates for assistance than they can do on their own, cannot be confirmed or rejected.

The analysis of both surveys, the first at the beginning of distance education and the second at the end of the academic year, showed that the suggestions provided by students in the first survey were considered. Also, the challenges they faced when completing the first survey were greatly reduced in percentage or did not occur again. As a result, in their opinion, they have improved the e-learning process with their proposals, referring to the one in which they were involved.

The survey was conducted based on professional literature in this field and self-evaluation reports of higher vocational schools (higher education, short cycle) in SE Slovenia. The considered view of e-learning cannot be traced in the academic literature, namely as COVID19 is relatively new and all higher vocational schools in Slovenia had to adapt and implement distance learning immediately.

The results of the research assist higher education institutions to identify the challenges that students face in the educational process. In this way, the research reveals the possibilities of various adjustments, such as consistency in the use of the same communication channel, implementation of education according to a pre-planned schedule, assisting teachers in using the online classroom, comprehensibility, and timeliness of instructions. Namely, the recognition of e-learning challenges by students is the basis for improving the entire e-learning process, which contributes to better achievement of educational goals, thus to a better educational process of individual schools and consequently to greater contribution of knowledge to society.

The research was limited to other research already conducted in this area. The questionnaire that was created was made as a pilot research on as large a sample as possible to obtain starting points for the implementation of improvements in practice and the possibility of further testing an even larger number of higher education students in Slovenia. The research also offers a starting point for the preparation of a questionnaire intended for teachers who have conducted 
e-learning, to examine their aspect of where they see further advantages in the e-learning process or where they identify challenges. There are also opportunities for further research, namely in the direction of identifying the advantages and disadvantages of direct education in relation to e-learning with a student population that has been fully subject to both modes of education. At that time, it would be easier to compare the findings with the findings of global research.

\section{References}

1. Almarashdeh, I., \& Alsmadi, M. (2016). Investigating the acceptance of technology in distance learning program. In 2016 International Conference on Information Science and Communications Technologies (ICISCT) (pp. 1-5). IEEE. doi:10.1109/ICISCT.2016.7777404

2. Al-Okaily, M., Alqudah, H., Matar, A., Lutfi, A., \& Taamneh, A. (2020). Dataset on the Acceptance of e-learning System among Universities Students' under the COVID-19 Pandemic Conditions. Data in brief, 32, 106176. doi.org/10.1016/j.dib.2020.106176

3. Aparicio, M., Bacao, F., \& Oliveira, T. (2016). An e-learning theoretical framework. An elearning theoretical framework, (1), 292-307.

4. Azlan, C. A., Wong, J. H. D., Tan, L. K., Huri, M. S. N. A., Ung, N. M., Pallath, V., ... \& Ng, K. H. (2020). Teaching and learning of postgraduate medical physics using Internet-based e-learning during the COVID-19 pandemic-A case study from Malaysia. Physica Medica. doi.org/10.1016/j.ejmp.2020.10.002

5. Baker, A. L. (2018). Communication and Trust in Virtual and Face-To-Face Teams. EmbryRiddle Aeronautical University. A Dissertation.

6. Boelens, R., De Wever, B., \& Voet, M. (2017). Four key challenges to the design of blended learning: A systematic literature review. Educational Research Review, 22, 1-18. doi.org/10.1016/j.edurev.2017.06.001

7. Bregar, L., Zagmajster, M., \& Radovan, M. (2019). E-izobraževanje za digitalno družbo. Andragoški Center Slovenije (in print).

8. Chalwell, A. (2020). The Training Experiences of Tenured Faculty Teaching Online: A Basic Qualitative Study. Capella University. A Dissertation.

9. Chege, M. W. (2019). Appraising of E-learning Accessibility in Central Kenyan Universities. Northcentral University. A Dissertation.

10. Cigler, S. (2016). Metodologija načrtovanja in strategija poučevanja kem. vsebin ob uporabi didaktičnih e-gradiv pri predmetu Naravoslovje na stopnji poklicnega izobraževanja (Doctoral dissertation, Univerza v Mariboru, Fakulteta za naravoslovje in matematiko).

11. Cidral, W. A., Oliveira, T., Di Felice, M., \& Aparicio, M. (2018). E-learning success determinants: Brazilian empirical study. Computers \& Education, 122, 273-290. doi.org/10.1016/j.compedu.2017.12.001

12. Coccoli, M., Maresca, P., \& Molinari, A. (2020). Big Data, Cognitive Computing, and the Future of Learning Management Systems. In Applied Degree Education and the Future of Work (pp. 329-340). Springer, Singapore. doi.org/10.1007/978-981-15-3142-2_25

13. Correia, A. P., Liu, C., \& Xu, F. (2020). Evaluating videoconferencing systems for the quality of the educational experience. Distance Education, 41(4), 429-452. doi.org/10.1080/01587919.2020.1821607 
14. Darrow-Magras, S. (2015). Returning to High School Online: A Phenomenological Study Exploring the Student Experience of Internet-Based Learning Self-Efficacy and Persistence. Northcentral University. A Dissertation.

15. Davidovitch, N., \& Belichenko, M. (2016). Developmental and Implementation Challenges of ELearning Management Systems in Higher Education. Higher Education Studies, 6(4), 170-180.

16. De Silva, V. (2019). Developing Self-regulated Learning skills in University students studying in the Open \& Distance Learning Environment by using KWL method.

17. Downes, S. (2005). E-learning 2.0. ELearn, 2005(10), 1.

18. Ferri, F., D’Andrea, A., Grifoni, P., \& Guzzo, T. (2018). Distant Learning: Open Challenges and Evolution. International Journal of Learning, Teaching and Educational Research, 17(8), 78-88. doi.org/10.26803/ijlter.17.8.5

19. Freeze, R. D., Alshare, K. A., Lane, P. L., \& Wen, H. J. (2019). IS success model in e-learning context based on students' perceptions. Journal of Information systems education, 21(2), 4. doi.org/10.1111/j.1540-4609.2011.00321.x

20. Gorse, C., Cozzens, R., Scott, L., \& Dickinson, I. (2019). Higher education in the professions: Illustrations of quality practice in teaching and learning. In Ensuring Quality in Professional Education Volume I (pp. 19-52). doi.org/10.1007/978-3-030-01096-6_2

21. Hasan, N., \& Bao, Y. (2020). Impact of “e-Learning crack-up" perception on psychological distress among college students during COVID-19 pandemic: A mediating role of "fear of academic year loss". Children and Youth Services Review, 118, 105355. doi.org/10.1016/j.childyouth.2020.105355

22. Hayashi, A., Chen, C., Ryan, T., \& Wu, J. (2020). The role of social presence and moderating role of computer self-efficacy in predicting the continuance usage of e-learning systems. Journal of Information Systems Education, 15(2), 5.

23. Khalid, A. H. (2020). An Exploratory Qualitative Study of the Potential for Enhanced E-learning in Public Higher Education in Afghanistan. Indiana University of Pennsylvania. A Dissertation.

24. Lamb, D., Knowles, L., Rattadilok, P., Towey, D., \& Walker, J. (2020). Can clicker technology and the latest online response systems enhance student engagement? a comparative study of two approaches. In Applied Degree Education and the Future of Work (pp. 287-301). Springer, Singapore. https://doi.org/10.1007/978-981-15-3142-2_22

25. Loh, C., D. H. Wong, A. Quazi, and R. P. Kings.hott. (2016). Re-examining Students' Perception of E-learning: An Australian Perspective. International Journal of Educational Management, 30(1), 129-139. doi.org/10.1108/IJEM-08-2014-0114

26. Manu, J. (2020). Strategies for Implementing e-Learning Solutions in Ghana's Public Universities: A Delphi Study.

27. Markova, T., Glazkova, I., \& Zaborova, E. (2017). Quality issues of online distance learning. Procedia-Social and Behavioral Sciences, 237, 685-691. doi.org/10.1016/j.sbspro.2017.02.043

28. Nortvig, A. M., Petersen, A. K., \& Balle, S. H. (2018). A Literature Review of the Factors Influencing E-Learning and Blended Learning in Relation to Learning Outcome, Student Satisfaction and Engagement. Electronic Journal of e-Learning, 16(1), 46-55.

29. Oyediran, W. O., Omoare, A. M., Owoyemi, M. A., Adejobi, A. O., \& Fasasi, R. B. (2020). Prospects and limitations of e-learning application in private tertiary institutions amidst COVID19 lockdown in Nigeria. Heliyon, e05457. doi.org/10.1016/j.heliyon.2020.e05457

30. Palgrave Macmillan, Cham.Gros, B., \& García-Peñalvo, F. J. (2016). Future trends in the design strategies and technological affordances of e-learning. Springer. doi:10.1007/978-3-319-177274_67-1 
31. Pesek, I., Lipovec, A., \& Zmazek, B. (2020). Video razlage kot učinkovit element izobraževanja v COVID 19 situaciji. doi: 10.31219/osf.io/eypzm

32. Potočnik, G. (2016). HASH (0xb098c68) (Doctoral dissertation, HASH (0xb0c9638)).

33. Robbie, N. (2020). A Narrative Inquiry Study on How Online Adult Learners Experience Teaching Presence. College of Professional Studies Northeastern University Boston, Massachusetts. A Dissertation.

34. Al-Samarraie, H., Teng, B. K., Alzahrani, A. I., \& Alalwan, N. (2018). E-learning continuance satisfaction in higher education: a unified perspective from instructors and students. Studies in Higher Education, 43(11), 2003-2019. doi.org/10.1080/03075079.2017.1298088

35. Shahmoradi, L., Changizi, V., Mehraeen, E., Bashiri, A., Jannat, B., \& Hosseini, M. (2018). The challenges of E-learning system: Higher educational institutions perspective. Journal of education and health promotion, 7. doi: 10.4103/jehp.jehp_39_18

36. Sohrabi, B., Vanani, I. R., \& Iraj, H. (2019). The evolution of e-learning practices at the University of Tehran: A case study. Knowledge Management \& E-Learning: An International Journal, 11(1), 20-37. doi.org/10.34105/j.kmel.2019.11.002

37. Stricker, D., Weibel, D., \& Wissmath, B. (2011). Efficient learning using a virtual learning environment in a university class. Computers \& Education, 56(2), 495-504. doi.org/10.1016/j.compedu.2010.09.012

38. Sukendro, S., Habibi, A., Khaeruddin, K., Indrayana, B., Syahruddin, S., Makadada, F. A., \& Hakim, H. (2020). Using an extended Technology Acceptance Model to understand students' use of e-learning during Covid-19: Indonesian sport science education context. Heliyon, 6(11), e05410. doi.org/10.1016/j.heliyon.2020.e05410

39. Sun, P. C., Tsai, R. J., Finger, G., Chen, Y. Y., \& Yeh, D. (2008). What drives a successful eLearning? An empirical investigation of the critical factors influencing learner satisfaction. Computers \& education, 50(4), 1183-1202. doi.org/10.1016/j.compedu.2006.11.007

40. Surber, A. M. (2017). E-learning Factors Influencing Strategies: Multi-Case Study of Employee Training at a Higher Educational Institution (Doctoral dissertation, Northcentral University).

41. Surma, T., \& Kirschner, P. A. (2020). Virtual special issue computers in human behavior technology enhanced distance learning should not forget how learning happens. Computers in Human Behavior, 110, 106390. doi: 10.1016/j.chb.2020.106390

42. Uppal, M. A. (2017). Addressing student perception of E-learning challenges in Higher Education holistic quality approach (Doctoral dissertation, University of Reading).

\section{Povzetek: \\ Izzivi nenadnega prehoda na e-izobraževanje}

Raziskovalno vprašanje (RV): Katere izzive so študentje pri nenadnem prehodu na eizobraževanje zaradi pojava virusa covid-19 prepoznali? S katerimi podanimi predlogi so pripomogli $\mathrm{k}$ izboljšanju izvedbe e-izobraževanja in $\mathrm{v}$ kolikšni meri je po mnenju študentov upoštevanje njihovih predlogov pripomoglo k boljšemu e-izobraževanju?

Namen: Z raziskavo želimo ugotoviti, katere izzive pri e-izobraževanju študentje višjih strokovnih šol zaznavajo. Zaradi nenadnega pojava virusa covid-19 se je način izobraževanja namreč takoj spremenil in pred številne izzive postavil tako učitelje kot študente.

Metoda: Za raziskavo smo uporabili različne študije, ki temeljijo na vsebinski analizi različnih člankov iz obstoječe literature tujih in domačih avtorjev. Uporabljeno literaturo smo prebrali in po ključnih besedah analizirali. Za potrebo raziskave smo informacije zbrali z uporabo anketiranja študentov JV Slovenije 7 različnih višješolskih programov. Vprašalnik je bil oblikovan na podlagi samoevalvacijskih poročil in predhodno analizirane strokovne literature, ki obravnava to tematsko področje. 
Rezultati: S proučevanjem tuje in slovenske literature in izvedbo ankete med študenti 7 višješolskih strokovnih programov JV Slovenije smo podali izsledke izzivov, s katerimi so se študentje pri nenadnem pojavu pandemije znašli pri e-izobraževanju. Z upoštevanjem predlogov s strani študentov smo izboljšali e-izobraževanje, v katerega so bili vsi vključeni, in jim tako olajšali učni proces.

Organizacija: Rezultati raziskave bodo šolam omogočili, da prepoznane izzive, ki so jih študentje zaznali, s pridom implementirajo $\mathrm{v}$ vzgojno-izobraževalni proces $\mathrm{z}$ namenom izboljšati eizobraževanje. Raziskava ponuja odgovor, na katerih mestih izboljšati e-izobraževanje in ga glede načina prilagoditi po meri študenta.

Družba: Prepoznavanje izzivov e-izobraževanja s strani študentov so temelj za izboljšanje celotnega procesa e-izobraževanja, kar doprinese $\mathrm{k}$ boljšemu doseganju izobraževalnih ciljev in večjemu doprinosu znanja družbi.

Originalnost: Več raziskav o e-izobraževanju je bilo že narejenih, nobene pa nismo zasledili, ki bi obravnavala izzive s strani višješolskih študentov ob nenadnem in nepričakovanem uvajanju eizobraževanja zaradi svetovne zdravstvene situacije.

Omejitve/nadaljnje raziskovanje: Omejili smo se na raziskave, ki so bile že narejene na tem področju. Vprašalnik, ki je nastal, je narejen kot pilotna raziskava na čim večjem vzorcu z namenom preverjanja vprašanj in dobiti izhodišča za implementacijo izboljšav v praksi in možnost nadaljnjega testiranja še večjega števila študentov. Prav tako raziskava ponuja izhodišče za pripravo vprašalnika, namenjenega predavateljem, ki so izvajali e-izobraževanje.

Ključne besede: e-izobraževanje, izzivi, študentje, anketni vprašalnik.

$$
* * *
$$

Monja Pust in 2001 obtained the scientific title of Master of Science of Slovenian Literature. She is employed as a professor and lecturer at a vocational college. She is currently pursuing a doctorate in quality management at the Faculty of Organizational Studies in Novo mesto.

Annmarie Gorenc Zoran is a Full Professor at the Faculty of Organisation Studies in Novo mesto as well as teaches distance learning courses abroad. Her research interest is an interdisciplinary approach to communication, as a channel in e-learning, framework for continuous improvement in terms of quality standards feedback, a tool in education and teaching, as an analytical framework to research, and as a contribution to management. She has worked and lead several international projects, is a journal editor, reviewer of journal articles and has published book chapters, numerous articles, and presented at international, national, and regional conferences. 